\title{
Rapid Screening of Permeation of Rutin through Skin Using Alaptide Enantiomers
}

\author{
Aneta Cernikova, Radka Opatrilova, Pavel Bobal and Josef Jampilek $\underline{\underline{ }}$ \\ Department of Chemical Drugs, Faculty of Pharmacy, University of Veterinary and Pharmaceutical Sciences, \\ Palackeho 1/3, 61242 Brno, Czech Republic \\ ${ }^{凶}$ Corresponding Author: E-mail: josef.jampilek@gmail.com; Tel.: +420-541-562-926
}

Received: December 21, 2014; Revised: December 22, 2014; Published: January 09, 2015

\begin{abstract}
The investigation deals with the influence of permeation of rutin from carboxymethyl cellulose gel through full-thickness pig ear skin by (S)- and (R)-alaptide as potential excipients. Alaptide, 8-methyl-6,9diazaspiro[4.5]decan-7,10-dione, is the original Czech compound. By means of this rapid screening it was found out that the permeation of rutin through the skin increased linearly with time and was enhanced by both enantiomers of alaptide: approx. 1.2-fold by (R)-alaptide and approx. 1.5-fold by (S)-alaptide.
\end{abstract}

\section{Keywords}

(S)-Alaptide; (R)-alaptide, rutin; carboxymethyl cellulose gel; skin permeation modifiers.

\section{Introduction}

Permeation modifiers (enhancers and retardants) affect the barrier properties of the skin. Chemical permeation enhancers (CPEs) are employed to increase the transdermal penetration of therapeutic agents [1-6 and refs. therein]. Alaptide, (S)-8-methyl-6,9-diazaspiro[4.5]decan-7,10-dione (see Fig. 1) was designed as an analogue of melanocyte-stimulating hormone release-inhibiting factor (MIF-1) [7-10] and thus is able to influence the creation and function of keratinocytes [11-13]. Based on these facts and structural analogy with other CPEs [4], it was suggested to investigate alaptide as a potential CPE of many anti-inflammatory drugs, antimicrobial chemotherapeutics, sex hormones/genital system modulators or drugs of central/vegetative nervous system [14-16]. Permeation through the skin of micronized and nanonized (S)-alaptide from semisolid formulations was investigated recently [17], and the transdermal modifying effect of micronized and nanonized $(S)$-alaptide was also described [14-16,18,19]. It was found that enhancers can become retardants in different formulation environments or when different particle sizes were used and vice versa. Since modifiers influence drug delivery, further exploration of these compounds is required to understand their modifying action on the properties of the skin.

Today more than $50 \%$ of marketed drugs are chiral. It has been well recognized that the stereochemistry of chiral drugs has a major influence on their pharmacological, pharmacokinetic and toxicological actions. Studies on enantiomeric differences in the percutaneous permeation of chiral compounds have been actively pursued in recent years. Stratum corneum, the rate-limiting barrier in 
transdermal permeation, is made up mainly of keratin and ceramides, which could potentially provide chiral environment. Transdermal delivery is facilitated by the presence of penetration enhancers, which act primarily by altering the diffusion by disrupting the highly ordered membrane structure or by affecting the partitioning behaviour of the diffusant molecules. Enantioselective permeation was observed with some chiral excipients, including, for example, terpene enhancers [20-22].

Based on the above mentioned facts and the excellent enhancement effect of $(S)$-alaptide [14-16], $(R)$-alaptide was prepared, and both enantiomers were tested by means of rapid screening for their ability to modify the skin barrier properties. Bioflavonoid glycoside rutin, 2-(3,4-dihydroxyphenyl)-5,7-dihydroxy-4oxo-4H-chromen-3-yl 6-O-(6-deoxy- $\alpha$-L-mannopyranosyl)- $\beta$-D-glucopyranoside, see Fig. 1 , was chosen as an model compound, since rutin is one of the most often used drugs for decreasing capillary permeability and for treatment of haemorrhoids, varicosis and microangiopathy [23]. Enhanced permeation through the skin and higher availability of the compound would be favourable for the treatment of vascular wall fragility. Within this study the permeation of rutin from carboxymethyl cellulose gel and subsequently the permeation of rutin with the addition of the individual enantiomers of alaptide as modifiers of transdermal permeation from the same formulation are investigated.

Flavonoids (bioflavonoids, Vitamin P) are a class of plant secondary phenolic metabolites. Today more than 4000 flavonoid-based compounds were described [24,25]. Flavonoids are glycosides containing aglycone derived from benzopyran (chromene) with lateral phenyl in the positions $\mathrm{C}_{(2)}, \mathrm{C}_{(3)}$ or $\mathrm{C}_{(4)}$ of the benzopyran scaffold. The phenyl rings are marked $A$ and $B$, and the pyran ring $C$ is ortho-condensed with the ring $A$. In nature flavonoids are substituted (especially in position 3 of the benzopyran scaffold) by various sugars and generate flavonoid glycoside. Aglycone or the glycosyl group can be substituted by a hydroxyacid $[25,26]$. Both aglycone and glycosides have biological effects. Bioflavonoids normalize permeability of capillaries and remove their fragility; they have antihaemorrhagic and anti-edematous effects [25-28]. Also antibacterial, antioxidant and anti-inflammatory activities are typical for them [25-28]. Bioflavonoids are used as venopharmaceuticals, i.e. drugs for the treatment of chronic venous insufficiency, superficial thrombophlebitis and haemorrhoids. They can be applied locally for the treatment of dermatomicroangiopathy, periphlebitis, haematomas and traumatic oedema [28].
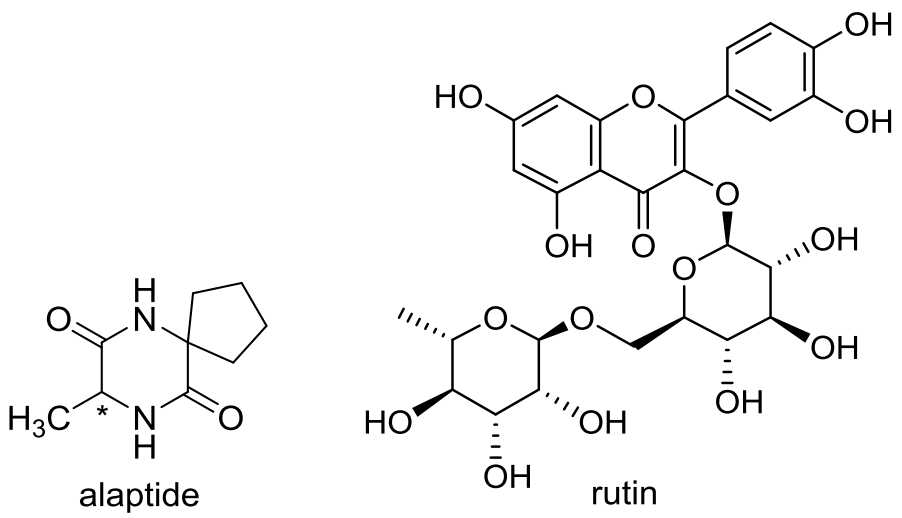

Figure 1. Structures of investigated compounds.

\section{Experimental}

\section{Preparation of alaptide}

Both alaptide enantiomers were synthesized by the standard process [29] and characterized [30]. The specific optical rotation of $0.2 \mathrm{~mol} / \mathrm{L}$ methanolic solution is $[\alpha]_{D}{ }^{20}=+21.2^{\circ}$ for the $(R)$-enantiomer and $[\alpha]_{D}^{20}=-21.2^{\circ}$ for the $(S)$-enantiomer. The melting point of $(S)$-alaptide is $232-234{ }^{\circ} \mathrm{C}$, while that of 
$(R)$-alaptide is $230-232^{\circ} \mathrm{C}$. Rutin was purchased from Sigma, all other reagents were purchased from Aldrich and Lach-Ner.

\section{Investigated Semisolid Formulations}

The composition of gel with $10 \%(\mathrm{w} / \mathrm{w})$ rutin was the following: rutin $10 \mathrm{~g}$ and carboxymethyl cellulose gel (carboxymethyl cellulose sodium $5 \mathrm{~g}$, macrogol $30010 \mathrm{~g}$, propylene glycol $2.5 \mathrm{~g}$, methylparaben $0.2 \mathrm{~g}$, propylparaben $0.2 \mathrm{~g}$ and purified water $87.3 \mathrm{~g}$ ) up to $100 \mathrm{~g}$. The composition of gel with the addition of alaptide $1 \%(\mathrm{w} / \mathrm{w}$; in relation to rutin amount) was the following: rutin $10 \mathrm{~g}$, alaptide $0.1 \mathrm{~g}$ and carboxymethyl cellulose gel up to $100 \mathrm{~g}$.

\section{In vitro transdermal permeation experiments}

Skin samples were obtained from porcine ear. Full thickness skin was cut in fragments and stored at $-20{ }^{\circ} \mathrm{C}$ until utilized. Skin samples were slowly thawed (at $4{ }^{\circ} \mathrm{C}$ overnight and then at ambient temperature) before each experiment. The permeation enhancing effect of both alaptide enantiomers was evaluated in vitro, using a vertical Franz diffusion cell (SES - Analytical Systems, Germany) with a donor surface area of $0.6359 \mathrm{~cm}^{2}$ and a receptor volume of $5.2 \mathrm{~mL}$. The skin was mounted between the donor and receptor compartments of the Franz diffusion cell with the epidermal side up. The receptor compartment was filled with phosphate buffered saline $(\mathrm{pH} 7.4)$ and maintained at $34.0 \pm 0.5^{\circ} \mathrm{C}$, using a circulating water bath. The receptor compartment content was continuously stirred using a magnetic stirring bar. The skin was kept in contact with the receptor phase for $0.5 \mathrm{~h}$ prior to the experiment. The investigated gel formulations were applied to the skin surface as a donor sample, and the donor compartment of the cell was covered by Parafilm ${ }^{\circledR}$. Samples $(0.5 \mathrm{~mL})$ of the receptor phase were withdrawn at five pre-determined time intervals $(30,60,90,120$ and $180 \mathrm{~min})$, and the cell was refilled with an equivalent amount of fresh buffer solution. A minimum of five determinations was performed using skin fragments from a minimum of 2 animals for each compound, and the data was expressed as means \pm SD. The samples were immediately analysed by HPLC.

The analysis of the samples was performed using an Agilent 1200 series HPLC system, equipped with a diode array detection (DAD) system, a quaternary model pump and an automatic injector (Agilent Technologies, Germany). Data acquisition was performed using ChemStation chromatography software. A Zorbax Eclipse XDB C18 $5 \mu \mathrm{m}, 4.6 \times 150 \mathrm{~mm}$ (Agilent, USA) chromatographic column was used. The total flow of the column was $0.5 \mathrm{~mL} / \mathrm{min}$; injection was $10 \mu \mathrm{L}$; column temperature was $30^{\circ} \mathrm{C}$; and sample temperature was $10^{\circ} \mathrm{C}$. The detection wavelength of $254 \mathrm{~nm}$ was chosen; the time of analysis was $10 \mathrm{~min}$. A mixture of $\mathrm{MeOH}$ (HPLC grade, $85.0 \%$ ) and $\mathrm{H}_{2} \mathrm{O}$ (HPLC - Mili-Q Grade, 15.0\%) was used as a mobile phase. The retention time $\left(t_{R}\right)$ of rutin was $3.70 \pm 0.05 \mathrm{~min}$; the limit of detection (LOD) was $0.99 \mathrm{ng} / \mathrm{mL}$; and the limit of quantification (LOQ) was $3.3 \mathrm{ng} / \mathrm{mL}$.

\section{Results and Discussion}

Rutin was chosen as a frequently applied venopharmaceutical for the topical treatment of the fragility of vascular wall that can be associated with various injuries of the skin, because alaptide itself shows significant curative effect on the skin [8,31]. The rapid in vitro skin permeation screening experiments were performed using static Franz diffusion cells [32] within 3 hours only. Full-thickness pig ear skin was selected for in vitro evaluation of permeation. This tissue is a suitable in vitro model of human skin [33], because porcine skin has shown to be histologically and biochemically similar to human skin, and it has been used in numerous studies [4]. The permeation of rutin through full-thickness pig ear skin without and with $1 \%$ 
(w/w related to rutin) $(S)$ - or $(R)$-enantiomer of alaptide was tested from carboxymethyl cellulose gel as a donor vehicle. All the results are provided in Table 1 and illustrated in Figure 2.

Table 1. Cumulative permeated amounts $Q_{t}$ per unit area $\left[\mu \mathrm{g} / \mathrm{cm}^{2}\right]$ of rutin from carboxymethyl cellulose gel without and with $(S)$-alaptide or $(R)$-alaptide as modifiers of transdermal permeation achieved in in vitro transdermal permeation experiments using Franz diffusion cell. $Q_{t}$ are expressed as mean \pm SD ( $n=5$ experiments).

\begin{tabular}{cccc}
\hline \multirow{2}{*}{ Time $[\mathrm{h}]$} & \multicolumn{3}{c}{ Cumulative permeated amounts $Q_{\mathrm{t}}$ per unit area[ $\left[\mathrm{Hg} / \mathrm{cm}^{2}\right]$} \\
\cline { 2 - 4 } & rutin & rutin+(S)-alaptide & rutin+(R)-alaptide \\
\hline 0.5 & $3.7 \pm 0.6$ & $5.5 \pm 0.7$ & $4.6 \pm 0.6$ \\
1.0 & $6.5 \pm 0.7$ & $9.7 \pm 0.9$ & $7.7 \pm 0.8$ \\
1.5 & $9.0 \pm 0.5$ & $15.4 \pm 1.0$ & $11.9 \pm 1.0$ \\
2.0 & $13.2 \pm 1.1$ & $19.4 \pm 1.2$ & $15.1 \pm 0.8$ \\
3.0 & $16.7 \pm 1.3$ & $25.9 \pm 1.5$ & $20.0 \pm 1.1$ \\
\hline
\end{tabular}

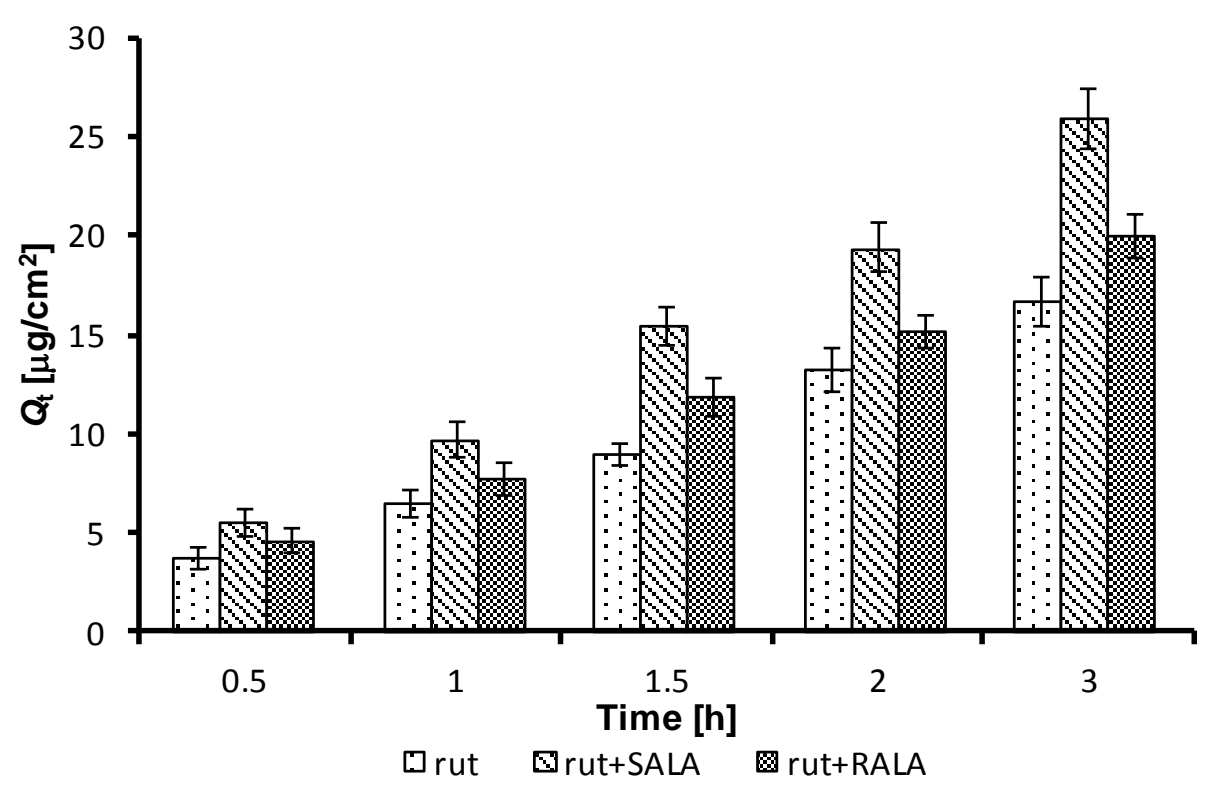

Figure 2. In vitro profile of cumulative permeated amounts $Q_{t}$ per unit area $\left[\mu \mathrm{g} / \mathrm{cm}^{2}\right]$ in time of rutin (rut) alone and after addition of $1 \% \mathrm{w} / \mathrm{w}$ of (S)-alaptide (SALA) or (R)-alaptide (RALA) from carboxymethyl cellulose gel through skin. $Q_{\mathrm{t}}$ values are expressed as mean $\pm \mathrm{SD}$ ( $n=5$ experiments).

As the presented study represents a preliminary rapid in vitro screening, all the experiments were performed only in the time range from 0.5 to $3.0 \mathrm{~h}$. The values obtained from the permeation experiments were expressed as the cumulative permeated amount of the drug $\left(Q_{t}[\mu \mathrm{g}]\right)$ per unit of skin surface area $\left(0.6359 \mathrm{~cm}^{2}\right)$, see Table 1 . Due to the short time interval of experiments steady-state permeation flux and lag time cannot be calculated, but this was not the aim of the experiments. The dependences of the cumulative permeated amount of the drug per unit of skin surface area in time $\left(Q_{t}\right.$ versus $\left.t\right)$ are shown in Figure 2. Based on the results it can be stated that permeation of rutin through the skin increased linearly with time; for rutin alone correlation coefficient was $r=0.9891$ and slope $5.95 \mu / \mathrm{cm}^{2} / \mathrm{h}$; for rutin with $(R)$-alaptide $r=0.9896$ and slope $7.16 \mu / \mathrm{cm}^{2} / \mathrm{h}$; and for rutin with $(S)$-alaptide $r=0.9915$ and slope $9.21 \mu / \mathrm{cm}^{2} / \mathrm{h}$. Based on the ratios slopes of the linear dependences $Q_{\mathrm{t}}$ versus t permeation enhancement within the studied time span (up to $3 \mathrm{~h}$ ) can be evaluated. The permeation of rutin with $(R$ )-alaptide was 1.22-fold higher than without the addition of $(R)$-alaptide. The addition of $(S)$-alaptide to carboxymethyl cellulose gel caused 1.54-fold higher permeation of rutin through the skin than from the 
formulation without $(S)$-alaptide. On the other hand, rutin permeated from the formulation containing $(S)$-alaptide only 1.27-fold more compared with $(R)$-alaptide.

As mentioned above the components of stratum corneum form a chiral environment, therefore there is potential for stereoselective interactions of an enhancer with skin components. Stereoselective interactions of individual drug enantiomers (e.g., propranolol, metoprolol, timolol, ketorolac, ketoprofen, flurbiprofen, ephedrine, oxybutynin, amlodipine) with the skin components involving different permeation rates of individual enantiomers through the skin were tested. Some authors found different permeation rates for enantiomers, while other studies showed no enantiomeric differences in the permeation [20-22,34-36]. Similarly, investigations of interactions of individual CPE enantiomers with the skin provided opposite results $[20,22,37,38]$; therefore additional studies are needed to be performed to answer whether the skin is an enantioselective membrane and given its mechanism of action, enhancer conformation can influence its enhancing properties or the differences in the permeation rates between the individual enantiomers are not related to any stereoselective interactions, but they can be explained only by different physicochemical properties.

\section{Conclusions}

The ability of $(S)$ - and $(R)$-alaptide to modify the permeation of rutin through the porcine ear skin was examined using the Franz cell in the rapid in vitro screening. Both enantiomers of alaptide applied in concentration $1 \% \mathrm{w} / \mathrm{w}$ related to the amount of rutin influenced the permeation of the drug from the carboxymethyl cellulose gel through the skin. According to the calculated cumulative permeated amount of the drug per unit of skin surface area in time, rutin with addition of the $(R)$-enantiomer of alaptide permeated 1.22-fold more than from the formulation without the alaptide enantiomers, and with addition of the $(S)$-enantiomer of alaptide permeated 1.54 -fold more than without the alaptide enantiomers. The permeation of rutin through the skin increased approximately linearly with time. It can be concluded that the presence of alaptide facilitated permeation of rutin.

Acknowledgements: This study was supported by the centralized development project "Improving qualification of students of Ph.D. educational programs \& postdoctorates of agricultural and veterinary branches through engagement in multidisciplinary interuniversity teams". (Studie byla finančně podpořena centralizovaným rozvojovým projektem "Zvyšování kvalifikace studentů doktorských studijních programů a post-doktorandů zemědělských a veterinárních oborů zapojením do multidisciplinárních meziuniverzitních týmü".)

\section{References}

[1] H.Y. Thong, H. Zhai, H.I. Maibach, Skin Pharmacology and Physiology 20 (2007) 272-282.

[2] I.B. Pathan, C.M Setty, Tropical Journal of Pharmaceutical Research 8 (2009) 173-179.

[3] R.K. Subedi, S.Y. Oh, M.K. Chun, H.K. Choi, Archives of Pharmacal Research 33 (2010) 339-351.

[4] J. Jampilek, K. Brychtova, Medicinal Research Reviews 32 (2012) 907-947.

[5] J. Jampilek, Journal of Bioequivalence \& Bioavailability 5 (2013) 233-235.

[6] D. Kaushik, P. Batheja, B. Kilfoyle, V. Rai, B. Michniak-Kohn, Expert Opinion Drug Delivery 5 (2008) 517-529.

[7] E. Kasafirek, J. Vanzura, I. Krejci, J. Krepelka, A. Dlabac, M. Valchar, (United Pharmaceutical Works \& Research Institute for Pharmacy and Biochemistry), Belg. 897843 (1984) \& CS 231227 (1986).

[8] S. Radl, E. Kasafirek, I. Krejci, Drugs of the Future 15 (1990) 445-447.

[9] R. Lapka, Journal of Pharmacy and Pharmacology, 43 (1991) 874-876.

[10] J. Jampilek, R. Opatrilova, A. Rezacova, Z Oktabec, J. Dohnal, (Faculty of Pharmacy, University of Veterinary and Pharmaceutical Sciences Brno), WO/2014/019556 A1 (2014). 
[11] J.A. McGrath, R.A. Eady, F.M. Pope, Rook's Textbook of Dermatology, 7th ed. T. Burns, S. Breathnach, N. Cox, C. Griffiths, (Eds)., Blackwell Publishing, Oxford, 2004, pp. 3-7.

[12] W. James, T. Berger, D. Elston. Andrews' Diseases of the Skin: Clinical Dermatology, 10th ed., Saunders-Elsevier, Philadelphia, 2006, pp. 5-6.

[13] F.M. Watt, BioEssays 8 (1988) 163-167.

[14] J. Jampilek, R. Opatrilova, L. Coufalova, A. Cernikova, J. Dohnal, (Faculty of Pharmacy, University of Veterinary and Pharmaceutical Sciences Brno), WO/2013/020527 A1 (2013).

[15] J. Jampilek, A. Cernikova, R. Opatrilova, J. Dohnal, (Faculty of Pharmacy, University of Veterinary and Pharmaceutical Sciences Brno), CZ PV 2013-1000 (2013).

[16] J. Jampilek, R. Opatrilova, L. Dvorakova, K. Brychtova, J. Dohnal, (Faculty of Pharmacy, University of Veterinary and Pharmaceutical Sciences Brno), CZ 304915 B6 (2014).

[17] R. Opatrilova, A. Cernikova, L. Coufalova, J. Dohnal, J. Jampilek, The Scientific World Journal, 2013 (2013), Article ID 787283 (8 pages).

[18] R. Opatrilova, J. Jampilek, ADMET \& DMPK 2 (2014) 56-62.

[19] A. Cernikova, R. Opatrilova, J. Jampilek, Military Medical Science Letters 83 (2014) 34-39.

[20] I.K. Reddy, T.R. Kommuru, A.A. Zaghloul, M.A. Khan, Critical Reviews in Therapeutic Drug Carrier Systems 17 (2000) 285-325.

[21] I.K. Reddy, R. Mehvar, Chirality in Drug Design and Development, Marcel Dekker, New York, 2004.

[22] K. Vavrova, J. Zbytovska, A. Hrabalek, Current Medicinal Chemistry 12 (2005) 2273-2291.

[23] Drug Bank ver. 4.1 - Rutin, http://www.drugbank.ca/drugs/DB01698 (December 12, 2014).

[24] A. Benthsath, S.T. Rusznyak, A. Szent-Gyorgyi, Nature 139 (1937) 326-327.

[25] Q.M. Andersen, K.R. Markham. Flavonoids: Chemistry, Biochemistry and Applications. CRC Press, Boca Raton, 2006.

[26] S. Kumar, A.K. Pandey. The Scientific World Journal 2013 (2013) Article ID 162750 (16 pages).

[27] L.H. Cazarolli, L. Zanatta, E.H. Alberton, M.S. Figueiredo, P. Folador, R.G. Damazio, M.G. Pizzolatti, F.R. Silva, Mini-Reviews in Medicinal Chemistry 8 (2008) 1429-1440.

[28] M.S. Gohel, A.H. Davies, Current Vascular Pharmacology 7 (2009) 303-308.

[29] E. Kasafirek, M. Rybak, I. Krejci, A. Sturs, E. Krepela, A. Sedo, Life Science 50 (1992) 187-193.

[30] O. Julinek, V. Setnicka, A. Rezacova, J. Dohnal, V. Vosatka, M. Urbanova, Journal of Pharmaceutical and Biomedical Analysis 53 (2010) 958-961.

[31] E. Kasafirek, L. Korbova, J. Kohout, M. Jiraskova, I. Krejci, A. Galatik, (United Pharmaceutical Works \& Research Institute for Pharmacy and Biochemistry), CS 276270 (1992).

[32] T.J. Franz, Journal of Investigative Dermatology 64 (1975) 190-195.

[33] U. Jacobi, M. Kaiser, R. Toll, S. Mangelsdorf, H. Audring, N. Otberg, W. Sterry, J. Lademann, Skin Research and Technology 13 (2007) 19-24.

[34] C.M. Heard, K.R. Brain, Chirality 7 (1995) 305-309.

[35] J. Valentova, K. Bauerova, L. Farah, F. Devinsky, Archives of Dermatological Research 302 (2010) 635-638.

[36] A. Zeng, C. Wang, B. Yuan, G. Yang, Q. Fu, Drug Development and Industrial Pharmacy 36 (2010) 724-734.

[37] J. Novotny, P. Kovarikova, M. Novotny, B. Janusova, A. Hrabalek, K. Vavrova, Pharmaceutical Research 26 (2009) 811-821.

[38] Y.S.R. Krishnaiah, A. Nada, Pharmaceutical Development and Technology 17 (2011) 574-582. 